\title{
Commentary: Rain, Sun, Soil, and Sweat: A Consideration of Population Limits on Rapa Nui (Easter Island) before European Contact
}

\author{
Carl P. Lipo ${ }^{1 *}$, Robert J. DiNapoli ${ }^{2}$ and Terry L. Hunt ${ }^{3}$ \\ 1 Department of Anthropology, Binghamton University, Binghamton, NY, United States, ${ }^{2}$ Department of Anthropology, \\ University of Oregon, Eugene, OR, United States, ${ }^{3}$ Honors College and School of Anthropology, University of Arizona, \\ Tucson, AZ, United States
}

Keywords: collapse, demography, Easter Island, model parameterization, open science

\section{A commentary on}

Rain, Sun, Soil, and Sweat: A Consideration of Population Limits on Rapa Nui (Easter Island) before European Contact

\section{OPEN ACCESS}

Edited by:

Scott Andrew Mensing University of Nevada, Reno,

United States

Reviewed by:

Ethan Cochrane

University of Auckland, New Zealand Atholl John Anderson, ANU College of Arts and Social

Sciences, Australia

*Correspondence:

Carl P. Lipo

clipo@binghamton.edu

Specialty section:

This article was submitted to

Paleoecology,

a section of the journal

Frontiers in Ecology and Evolution

Received: 21 November 2017 Accepted: 28 February 2018

Published: 14 March 2018

Citation:

Lipo CP, DiNapoli RJ and Hunt TL (2018) Commentary: Rain, Sun, Soil, and Sweat: A Consideration of

Population Limits on Rapa Nui (Easter Island) before European Contact.

Front. Ecol. Evol. 6:25.

doi: 10.3389/fevo.2018.00025 by Puleston, C. O., Ladefoged, T. N., Haoa, S., Chadwick, O. A., Vitousek, P. M., and Stevenson, C. M. (2017). Front. Ecol. Evol. 5:69. doi: 10.3389/fevo.2017.00069

Rapa Nui (Easter Island) has long-presented a challenge to researchers seeking to explain the nearly 1,000 multi-ton statues carved and more than 600 transported across this tiny, remote island where Europeans observed a population just a few thousand in number. The stark contrast between the island's impressive monuments and its marginal resources led to early European speculations of a once larger population under more prosperous conditions, most famously espoused in Diamond's (2005) narrative of "collapse." Recently, Puleston et al. (2017) bring needed attention to the issue of pre-contact population size for Rapa Nui to examine the "collapse" debate. Their work combines demographic and agricultural productivity modeling with parameter estimates from Rapa Nui and other Pacific Islands. While such modeling has many strengths, their conclusion-that the island once supported a population of 17,500 - is based on questionable assumptions and contradicts a range of available evidence.

Given early European observations, the conclusion that Rapa Nui once supported a population of 17,500 requires a pre-European demographic collapse, in contradiction to archeological and historical evidence, including some of the authors' own work (e.g., Mulrooney et al., 2009, 2010; Stevenson et al., 2015). Predilections for large population estimates follow assumptions, sometimes tacit, that hundreds or even thousands of workers were needed to make and move the multi-ton statues and even more required to produce surplus food in support of these activities. Recent quantitative analyses and experiments demonstrate that relatively small numbers of people could transport the statues (Lipo et al., 2013). Popular notions of "collapse" can be traced to historical misconceptions as some have described (e.g., Lipo and Hunt, 2009; Mulrooney et al., 2009; Hunt and Lipo, 2011). There are currently few archeological indications that the population was ever much larger than the ca. 3,000 witnessed at European contact (Hunt and Lipo, 2009) or clear evidence for the precipitous decrease in land-use expected in a massive precontact population decline (Mulrooney et al., 2010; Mulrooney, 2013; Stevenson et al., 2015) required if Puleston et al.'s conclusions were valid. In addition, there is little evidence for the level of conflict expected with a dense population of 17,500 on such a small island, including limited lethal skeletal trauma, no systematic production of lethal weapons, nor fortifications 
(Lipo and Hunt, 2009; Hunt and Lipo, 2011; Gill and Stefan, 2016; Lipo et al., 2016; Owsley et al., 2016; DiNapoli et al., in press). Moreover, Rapa Nui lacks the kind of dense, nucleated settlement pattern often cited for elsewhere in Polynesia and expected for 17,500 inhabitants on a $164 \mathrm{~km}^{2}$ island (Kirch, 1984, 2017; Morrison and O'Connor, 2015). Early European population estimates around 3,000 are consistent with an archeologicallydocumented low-density and dispersed settlement structure (McCoy, 1976; Morrison, 2012).

The population estimate of 17,500 chosen by the authors reflects a fallacy of averaging where the number argued as the "most likely" is arbitrary and apparently little more than subjective preference. In their modeling, maximum population size ranged from 0 to 30,000 , but they do not explain how or why the mean is an accurate estimate of the "true" number. Moreover, and as emphasized by the authors, the outcomes are highly dependent on how they chose to parameterize the model, with $\mathrm{N}$ values, length of fallow period, amount of labor participation, fertility controls, and degree of surplus used to support "elites" being critical. Yet, the critical soil $\mathrm{N}$ values are not well understood, and there are essentially no archeological or ethnographic data available that would allow the authors to estimate these model parameters in a valid way. From a modeling perspective, lacking reasonable parameter values, one must choose outcomes that best fit any empirical evidence. In the authors' "low-N" scenarios, average population sizes are around 3,500, in contrast to their preferred 17,500 in the "high-N" situations. Based on limited evidence for Rapa Nui, the low-N values are just as likely, or more likely, than the high- $\mathrm{N}$ values. The results of the low- $\mathrm{N}$ scenarios, however, do correspond to the limited empirical demographic evidence we have-the observations of early European visitors. Finally, paleopathological evidence of dietary stress (e.g., enamel hypoplasia, Polet, 2006), suggests that the lower values are consistent with the conditions of food-limited demography for the island.

Importantly, their model neglects annual variance in agricultural productivity. When there is variance in productivity, population growth is limited by minimal productivity and better modeled using the geometric mean rather than the arithmetic mean (Renshaw, 1993; Nations and Boyce, 1997; Freckleton and Watkinson, 1998, p. 113), and populations in variable environments can stabilize at substantially lower levels than under more constant conditions. Rapa Nui has unpredictable annual rainfall and on longer-term timescales, resulting in potentially substantial variability in food productivity (Genz and Hunt, 2003; Morrison, 2012). Consequently, models ignoring temporal variability could,

\section{REFERENCES}

Boyce, M. S., Haridas, C. V., Lee, C. T., and the NCEAS Stochastic Demography Working Group (2006). Demography in an increasingly variable world. Trends Ecol. Evol. 21, 141-148. doi: 10.1016/j.tree.2005.11.018

Diamond, J. (2005). Collapse: How Societies Choose to Fail or Succeed. New York, NY: Viking. and likely, dramatically overestimate population sizes (Boyce et al., 2006; Lee et al., 2009). As Maynard Smith (1974, p. 13; cited in Boyce et al., 2006, p. 141) points out, "the use of deterministic rather than stochastic models can only be justified by mathematical convenience." The significance of variance in productivity also raises the question whether Hawai' $i$ or other comparisons to Rapa Nui's mean growing productivity are warranted. In the Pacific, Rapa Nui is distinctive in its poor soil fertility, seasonality, pre-contact land-use, settlement patterns, and investments in monument construction, making analogs with other islands potentially misleading.

In addition to the issues raised, this study suffers from problems of irreproducibility. The authors do not provide comprehensive data, adequate description of methods, computer code, or results needed to replicate or verify the outcomes of their model; at odds with current best-practices in science, and in archeology in particular (e.g., Marwick et al., 2017). Studies that include relatively complex computational models, but no code or necessary data needed for model replication, remain essentially unverifiable "black boxes" (Morin et al., 2012).

Ultimately, building an empirically supported and theoretically sound framework for estimating past populations of Rapa Nui is vital to explaining the remarkable archeological record of the island. We need good demographic models with empirically estimated parameters, including longer-term variability in productivity and, critically, whose outcomes can be replicated and evaluated against the archeological record. In the case of Puleston et al. the problems are not necessarily embedded in the model, but in unsound assumptions and a conflation of what might be possible with what is probable. Successful models depend on dynamic and empirical sufficiency (sensu Lewontin, 1974) and are evaluated on the degree to which they are useful. Thus, if the results of a model contradict multiple lines of empirical evidence, then the model is not wrong, but instead not useful for this particular case. Such is the case in this study of pre-contact Rapa Nui.

\section{AUTHOR CONTRIBUTIONS}

$\mathrm{CL}, \mathrm{RD}$, and $\mathrm{TH}$ : wrote the paper. All authors gave final approval for publication.

\section{ACKNOWLEDGMENTS}

We thank Alex E. Morrison and two reviewers for critical feedback on this manuscript. and Rapa Iti. J. Isl. Coast. Archaeol., 1-18. doi: 10.1080/15564894.2016.1276490 Freckleton, R. P., and Watkinson, A. R. (1998). How does temporal variability affect predictions of weed population numbers? J. Appl. Ecol. 35, 340-344.

Genz, J., and Hunt, T. L. (2003). El Niño/Southern oscillation and Rapa Nui prehistory. Rapa Nui J. 17, 7-14. 
Gill, G. W., and Stefan, V. H. (2016). "Rapanui origins, relationships, and warfare: A summary in theoretical context," in Skeletal Biology of the Ancient Rapanui (Easter Islanders), eds V. H. Stefan and G. W. Gill (Cambridge: Cambridge University Press), 286-302.

Hunt, T. L., and Lipo, C. P. (2009). Revisiting Rapa Nui (Easter Island) “'ecocide.” Pac. Sci. 63, 601-616. doi: 10.2984/049.063.0407

Hunt, T. L., and Lipo, C. P. (2011). The Statues That Walked: Unraveling the Mystery of Easter Island. New York, NY: Free Press.

Kirch, P. V. (1984). The Evolution of the Polynesian Chiefdoms. Cambridge: Cambridge University Press.

Kirch, P. V. (2017). On the Road of the Winds: An Archaeological History of the Pacific Islands before European Contact. Oakland, CA: University of California Press.

Lee, C. T., Puleston, C. O., and Tuljapurkar, S. (2009). Population and prehistory III: food-dependent demography in variable environments. Theor. Popul. Biol. 76, 179-188. doi: 10.1016/j.tpb.2009.06.003

Lewontin, R. C. (1974). The Genetic Basis of Evolutionary Change. New York, NY: Columbia University Press.

Lipo, C. P., and Hunt, T. L. (2009). A.D. 1680 and Rapa Nui prehistory. Asian Perspect. 48, 309-317. doi: 10.1353/asi.2009.0001

Lipo, C. P., Hunt, T. L., and Haoa, S. R. (2013). The 'walking' megalithic statues (moai) of Easter Island. J. Archaeol. Sci. 40, 2859-2866. doi: 10.1016/j.jas.2012.09.029

Lipo, C. P., Hunt, T. L., Horneman, R., and Bonhomme, V. (2016). Weapons of war? Rapa Nui mata'a morphometric analyses. Antiquity 90, 172-187. doi: 10.15184/aqy.2015.189

Marwick, B., d'Alpoim Guedes, J., Barton, C. M., Bates, L. A., Baxter, M., Bevan, A., et al. (2017). Open Science in Archaeology. SAA Archaeol. Rec. 17, 8-14. doi: 10.17605/OSF.IO/3D6XX

Maynard Smith, J. (1974). Models in Ecology. Cambridge: Cambridge: University Press.

McCoy, P. C. (1976). Easter Island Settlement Patterns in the Late Prehistoric and Protohistoric Periods. New York, NY: Easter Island Committee.

Morin, A., Urban, J., Adams, P. D., Foster, I., Sali, A., Baker, D., et al. (2012). Shining light into black boxes. Science 336, 159-160. doi: $10.1126 /$ science. 1218263

Morrison, A. (2012). An Archaeological Analysis of Rapa Nui Settlement Structure: A Multi-Scalar Approach. Dissertation, University of Hawai' i, Mānoa Honolulu, HI.

Morrison, A. E., and O'Connor, J. T. (2015). "Settlement pattern studies in Polynesia: past projects, current progress, and future prospects," in The Oxford Handbook of Prehistoric Oceania, eds E. E. Cochrane and T. L. Hunt (Oxford: Oxford University Press), 1-18.

Mulrooney, M. A. (2013). An island-wide assessment of the chronology of settlement and land use on Rapa Nui (Easter Island) based on radiocarbon data. J. Archaeol. Sci. 40, 4377-4399. doi: 10.1016/j.jas.2013.06.020
Mulrooney, M. A., Ladefoged, T. N., and Stevenson, C. M. (2010) "Empirical assessment of a pre-European societal collapse on Rapa Nui (Easter Island)," in The Gotland Papers: Selected Papers from the VII International Conference on Easter Island and the Pacific, eds P. Wallin and H. Martinsson-Wallin (Gotland: Gotland University Press), 141-153.

Mulrooney, M. A., Ladefoged, T. N., Stevenson, C., and Haoa, S. (2009). The myth of AD 1680: new evidence from Hanga Ho'onu, Rapa Nui (Easter Island). Rapa Nui J. 23, 94-105.

Nations, C. S., and Boyce, M. S. (1997). "Stochastic demography for conservation biology," in Structured-Population Models in Marine, Terrestrial, and Freshwater Systems, eds S. Tuljapurkar and H. Caswell (Boston, MA: Springer), 451-469.

Owsley, D. W., Barca, K. G., Simon, V. E., and Gill, G. W. (2016). "Evidence for injuries and violent death," in Skeletal Biology of the Ancient Rapanui (Easter Islanders), eds V. H. Stefan and G. W. Gill (Cambridge: Cambridge University Press), 222-252.

Polet, C. (2006). Indicateurs de stress dans un échantillon d'anciens Pascuans. Antropo 11, 261-270. Available online at: www.didac.ehu.es/antropo

Puleston, C. O., Ladefoged, T. N., Haoa, S., Chadwick, O. A., Vitousek, P. M., and Stevenson, C. M. (2017). Rain, sun, soil, and sweat: a consideration of population limits on Rapa Nui (Easter Island) before European contact. Front. Ecol. Evol. 5:69. doi: 10.3389/fevo.2017. 00069

Renshaw, E. (1993). Modelling Biological Populations in Space and Time. New York, NY: Cambridge University Press.

Stevenson, C. M., Puleston, C. O., Vitousek, P. M., Chadwick, O. A., Haoa, S., and Ladefoged, T. N. (2015). Variation in Rapa Nui (Easter Island) land use indicates production and population peaks prior to European contact. Proc. Natl. Acad. Sci. U.S.A. 112, 1025-1030. doi: 10.1073/pnas.14207 12112

Conflict of Interest Statement: The authors declare that the research was conducted in the absence of any commercial or financial relationships that could be construed as a potential conflict of interest.

The reviewer EC declared a past co-authorship with two of the authors, CL and $\mathrm{TH}$, to the handling Editor.

Copyright (C) 2018 Lipo, DiNapoli and Hunt. This is an open-access article distributed under the terms of the Creative Commons Attribution License (CC BY). The use, distribution or reproduction in other forums is permitted, provided the original author(s) and the copyright owner are credited and that the original publication in this journal is cited, in accordance with accepted academic practice. No use, distribution or reproduction is permitted which does not comply with these terms. 